\title{
KONSEP ONTOLOGI DAKWAH SUNAN KALIJOGO RELEVANSINYA BAGI PERKEMBANGAN MASYARAKAT PADA MASA KINI
}

\author{
Wahyudin \\ Institut Agama Islam Negeri (IAIN) Metro \\ Jalan Ki Hajar Dewantara 15 A Iring Mulyo Kota Metro \\ wahyudinyudi34@yahoo.com
}

\begin{abstract}
The figures spread the religion of Islam in Java will not be separated from the role of Walisongo in the grounding of Islamic teachings are very famous and especially sunan Kalijogo. The fame of Kalijogo sunan because he is a magic scholar and intelligent. He is a politician who raises the kings of some Islamic kingdoms, and is known as a well-mannered humanist and well-known puppet artist and artist. The historical review of Javanese society at that time still feels so reluctant to throw away the old teachings that are firmly attached. So depart from the thought in order to achieve its goals and ease in the spread of Islam in the land of Java, without the intention to mix up shari'ah with ancestral culture, sunan kalijogo make existing treasures as a means to neutralize the ancient society's assumptions Still leads to idolatry.

This ontological concept will reveal a new horizon about the impression on the story of walisongo, especially Kalijogo that tend to be less valuable among the masyarkat, especially Muslims. If an ontological horizon or nuance is found and a new image of walisonggo Sunan Kalijogo will tend to be uniform and thus will bring the distance between a story that is known to a more rational one. In turn, a new picture of Indonesian history in which local wisdom can be explained more clearly can be explained through the nuances of ontology as part of the philosophical study.
\end{abstract}

Key words: Philosophical approach, da'wah, tradition, and society 


\section{A. PENDAHULUAN}

Kearifan lokal akan bermakna apabila kearifan tersebut disampaikan dengan secara bijaksana melalui pendekatan filosofis. Pendekatan filosofis secara ontologis sangat diperlukan untuk mengungkap fenomena-fenomena yang sifatnya abtraksi. Sebagaimana yang digambarkan dalam filsafat Hegel, merupakan usaha untuk mencakup segenap kenyataan dalam suatu sitem yang meliputi segala-galanya. Bertolak dari pengertian tentang "Yangada yang murni" ("Pure Being"), Hegel berusaha menggagas tentang metafisika, alam fisik dan manusia. ${ }^{1}$ Artikel ini dalam rangka untuk menggali potensi filsafat local (Lokal Wisdom), sebagi wawasan keindonesiaan yang merupakan kearifan lokal. Keberadaan kearifan lokal diantaranya budaya, agama, adat istiadat yang telah mengakar dalam diri masyarakat sejak masa masyarakat itu ada dari Sabang sampai Merauke.

Konsep mengenai ontologi akan menguak cakrawala baru tentang kesan terhadap ceritera Sunan Kalijogo yang cenderung bernilai dikalangan masyarkat. Apabila cakrawala ataupun nuansa ontologis berhasil ditemukan dan dikemukakan gambaran baru tentang dakwah "Sunan Kalijogo" akan cenderung seragam dan demikian akan mendekatkan jarak antara dari sebuah ceritera-cerita khayal yang selama ini dikenal kepada yang lebih rasional.

Ketenaran sunan Kalijogo karena dia seorang ulama yang sakti dan cerdas. Sunan Kalijogo merupakan wali yang paling populer dimata orang jawa, bahkan sebagaian orang jawa menganggap sebagai guru agung dan suci ditanah jawa. ${ }^{2}$ Perspektif sejarah masyarakat jawa pada masa itu masih merasa begitu keberatan untuk membuang ajaran lama yang melekat dengan kuat. Sunan Kalijogo menjadikan khazanah lama sebagai sarana untuk menetralisir anggapan masyarakat yang masih mengarah pada kemusyrikan secara sedikit demi sedikit menuju pada ketauhidan murni. ${ }^{3}$ Namun realitas masa kini masih ada beberapa adat lama yang tampak melekat hingga kepada generasi

1 Harry Hamersna, Tokoh Tokoh Filsafat Barat Modern (Jakarta: Gramedia, 1984), h. 68.

2 Purwadi, Dakwah Walisongo, Penyebaran Islam Berbasis Kultural di Tanah Jawa, (Yogyakarta: Panji Pustaka, 2007), h. 21

3 Makhdlori Muhammad, Pertarungan Menuju Surga, Kala ajaran Spiritual Di Tunggangi Ambisi, Kemelut Warisan Spiritual Syekh Siti Jenar VS Sunan Kalijogo, (Yogyakarta: Diva Press,. 2006), h.7 
penerusnya, seperti slametan, tahlilan. Dakwah sunan Kalijogo menyebarkan Islam dengan cara mengembara. ${ }^{4}$ Sunan kalijogo seorang wali yang memiliki kepandaian tersendiri ahli seni, ahli filsafat budayawan dan negarawan. Tata cara berdakwahnya, kepercayaan lama dan adat istiadat tidak ditentang begitu saja. ${ }^{5}$ Selain di bidang dakwah Sunan kalijogo sangat besar peran didalam konteks kenegaraan, fungsi para waliyul amri itu adalah memberi nasehat tentang tata cara pelaksanaan pemerintahan negara. ${ }^{6}$ Sunan kalijogo hidup pada masa era dekade pemerintahan negara yakni masa Majapahit (sebelum 1487), kesultanan Demak (1481-1546), Kesultanan pajang (1546-1568) dan awal pemerintahan mataram (1580-an). ${ }^{7}$ Pada hakikatnya dakwah sunan kalijogo sebuah konsepsi ontologis bagi bangsa Indonesia yang beraneka ragam budaya dan berbeda-beda bahasa untuk memperkuat nilai kebangsaan yang saat ini mulai hilang.

\section{B. KONSEP ONTOLOGI}

Persoalan filsafat dakwah lebih lanjut lagi di pertajam pada persoalan ontologi dakwah. Sebagaian dari filsafat sistematis adalah metafisika. Dan ontologi merupakan sebagian dari filsafat sistematis. Ontologi menyelidiki sifat dasar apa yang nyata secara fundamental dapat dikatakan ada. ${ }^{8}$ Dalam kerangka tradisionel ontologi dianggap sebagai teori mengenai prinsip-prinsip umum mengenai hal ada. ${ }^{9}$ Ontologi berusaha mengungkap makna eksistensi, termasuk mengenai asal mula perkembangan dan stuktur kosmos (alam semesta). ${ }^{10}$ Arah kemestaan kenyataan perhatian analisis pertama-tama diarahkan oleh kenyataan itu

4 Ibid. 63

5 Saymasuri Baidlowi, Kisah Wali songo, (Surabaya: Apollo,1995), h.96

${ }^{6}$ Sofwan Ridin, 2004, Op cite, h.122

7 Purwadi, 2007, Log cite, h.213

8 The Liang Gie, Suatu Konsepsi Ke arah Penertiban Bidang Filsafat, Yogyakarta (Karya Kencana, 1977), h.97

9 Sulthon Muhammad, Menjawab Tantangan Zaman, Desain Ilmu Dakwah, Kajian Ontologis, Epistimologis dan Aksiologis, (Yogyakarta: Pustaka Pelajar, 2003), h.53

10 The Liang Gie, Op cite, 1977, h.80 
sendiri. ${ }^{11}$ Sebab ontologi cabang metafisika mengenai realitas yang mengungkap ciri-ciri yang ada. ${ }^{12}$

Namun dalam kaitan dengan filsafat keilmuan ontologi dari filsafat dakwah berkaitan dengan pandangan tentang hakikat ilmu atau pengetahuan ilmiah disekitar peroalan dakwah. ${ }^{13}$ Dengan demikian aspek ontologi dalam permasalahan ini pada eksistensi dakwah, apa yang nyata secara fundamental dalam dakwah. Dengan demikian, ada hubungan dengan Islam, dakwah fitrah manusia dan kebenaran. Dakwah dalam prakteknya merujuk pada fitrah manusia karena dalam fitrah itulah ada kebenaaran yang dengan begitu kebenaran akan hadir pada diri manusia dan diterima dengan ketulusan.

\section{TERMINOLOGI DAKWAH}

Dakwah adalah usaha yang mengarah untuk memperbaiki suasana kehidupan yang lebih baik dan layak dengan kehendak dan tuntutan kebenaran. ${ }^{14}$ Usaha membuka konfrontasi keyakinan ditengah manusia, membuka kemungkinan bagi kemanusiaan untuk menetapkan kemungkinannya sendiri. ${ }^{15}$ Dakwah adalah mendorong (memotivasi) umat manusia aagar melaksanakan kebaikan dan mengikuti petunjuk kebaikan. ${ }^{16}$ Sedangkan menurut bahy dakwah adalah standar nilai-nilai kemanusiaan dalam tingkah laku proibadi-pribadi di dalam hubungannya antar manusia dan sikap prilaku antar manusia. ${ }^{17}$

Perjuangan melawan keburukan dan kebobrokan serta kejahatan itu memerlukan kesanggupan melawan risiko yang berat,

11 Anton Baker, Ontologi Metafiska Umum, filsafat pengada, (Yogyakarta: Kanisius 1992), h.247

12 Fatimah Irma, Filsafat Islam, Ontologi, Epistimologi, Aksiologi, (Yogyakarta: Perspektif, 1992), h.5

13 Agus Bustanuddin, Pengembangan Ilmu-Ilmu Sosial, Studi Banding Antara Pandangan Ilmiah dan Ajaran Islam, (Jakarta: Gema Insani Press 1999), h.23

14 Zarkasi Effendi, Metode Dakwah Kepada Suku Terasing, (Jakarta: Departemen Agama, 1978) , h.4

${ }^{15}$ Isa Anshari, Mujahid Dakwah, (Bandung: Diponegoro, 1984), h.19

${ }_{16}$ Mahfudz Syekh Ali, Hidayat Al-Mursyidin, (Mesir: Dal al- Mishr, 1975), h. 7

17 Muhammad al Bahy, al-Sabil ila Dakwah al-Haq, (Kairo: Matbaah alAzhar, 1970), h.4 
kesabaran dalam menanggung pahit getir dan pedih perih guna tegaknya kebenaran. ${ }^{18 S e l a i n}$ itu, dakwah dapat pula digolongkan ke dalam salaf ash-shalih. ${ }^{19}$

Dakwah bersumber pada alqur'an adalah sumber nilai dan ajaran Islam yang paling utama. Nilai-nilai kebenaran yang terkandung alqur'an tidak diragukan lagi. Percaya tidak asal percaya tidak dapat disamakan dengan kepercayaan yang didasarkan atas pengetahuan dan pemahaman. Bahwa Alqur'an diturunkan dengan mengemban tiga fungsi dakwah, yaitu sebagai petunjuk (hudan) bagi manusia, sebagai penjelasan (bayyinah) mengenai petunjuk itu serta sebagai pembeda (furqan) antara yang haq dan yang bathil. ${ }^{20}$ Pembahasan filsafat dakwah bukan sematamata mengenai materi pesan dalam dakwah yang didekati secara filosofis, melainkan berkaitan dengan keutuhan dakwah sebagai subtansi. ${ }^{21}$ Proses dari sebuah dakwah membutuhkan pemikiran yang mendalam yang berkeinginan dalam hatinya untuk menjadi $37 \mathrm{~h}$ baik. ${ }^{22}$ Mengkaji persoalan alasan manusia memerlukan ayama, mengapa agama perlu di dakwahkan, apa tujuan akhir dari dakwah dan persoalan etika dakwah serta rasionalisasi hal-hal yang timbul dari dakwah. ${ }^{23}$ Agama samawi telah diturunkan Tuhan dan didakwahkan merupakan bukti-bukti yang benar (valid) sebagai nilai esensial untuk semua umat manusia (rahmatallil alamin).24 Alqur'an dan Hadits menjadi suatu tonggak dasar dan tiada suatu masalah. 25

Untuk memudahkan dan menopang tugas dakwah tersebut para pimpinan menciptakan uger-uger (aturan pergaulan hidup), wewara

18 Tahir Abd Muin, Diktat Kuliah Ilmu Dakwah, (Jqakarta: Tanggal 26 November 1958), h.7

${ }^{19}$ Hamka, Perkembangan Tasauf, (Jakarta: Grafiti Pers, 1952), h. 193

20 Tim Dosen Mata Kuliah Pendidikan Agama Islam, Memahami Hakikat Beragama, (Malang: Universitas Brawijaya, Penerbit Pusat Pembinaan Agama (PPA), 2002), h.71

${ }^{21}$ Farid Sayuti Imam, Intisari Filsafat Dakwah, (Surabaya: IAIN Sunan Ampel, 1989), h.5

${ }^{22}$ Gea Antonius Atosoki, 2004, Op cite, h. 21

23 Imam Farid Sayuti, 1989, Op cite, h.7

24 Sidi Gazalba, Ilmu Filsafat dan Islam tentang Manusia dan Agama, (Jakarta: Bulan Bintang, 1978), h.136

${ }^{25}$ Ali Rahmat M.H.A, OT, Beberapa Segi Masyarakat Islam, (Jakarta: Grrafiti pers, 1973), h.73 
(petuah) dan wewaler (pantangan) guna menjaga keserasian antara manusia dengan masyarakat dan manusia dan lingkungan tempat di mana ia hidup. Namun demikian, semua filsuf cenderung memperluas prinsip-prinsip tertentu dari seluruh kenyataan. ${ }^{26}$

Para wali adalah orang-orang yang dekat Allah yang terpelihara dari kemaksiatan. ${ }^{27}$ Manusia sebagai mahkluk metafisik mampu berfikir, bernalar, manusia tidak saja memikrkan dan memahami apa yang dilihatnya secara empiris dan relatif, akan tetapi juga mengatasi sebagai mana yang terjadi pada wali songo. ${ }^{28}$ Para wali itu melaksanakan dakwahnya disesuaikan dengan kondisi sosial masyarakat masing-masing berhubungan secara kuluralfungsional. ${ }^{29}$

\section{ONTOLOGI DAKWAH SUNAN KALIJOGO}

Istilah Ontologi berasal dari bahasa Yunani" "to on hei on, ontos artinya " Yang-Ada sebagai Yang-ada (a being as being) ${ }^{30}$ sehingga kita dapat melakukan atas makna yang terkandung dalam makna filosofis dari suatu kehihupan. Ontologi membahas asas-asas rasional dari kenyataan. ${ }^{31}$ Berdasarkan teori tersebut konsep dasar dakwah Sunan Kalijaga secara ontologis dari sebuah pemikirannya untuk membuat ide pemikiran sebagai teori filosofis dan sebagai falsafah hidup.

Reaksi saling tergantung dan saling memberi terdapat dalam totalitas, maknanya secara melekat pada diri manusia terbawa oleh keberadaan manusia secara alami memberikan karakteristik pada manusia 1). Manusia adalah makhluk yang saling tergantung antara satu dan lainnya, 2). Tugas hidup manusia adalah memberi kepada lingkungannya. ${ }^{32}$ Berasarkan teori ontologi tersebut keberadaan Sunan Kalijaga esensinya mempunyai makna yang besar dalam kiprah dakwah Islam sebab mempunyai peran yang 1996), h.22

${ }^{26}$ Louis Katsoff, Pengantar Filsafat, (Yogjakarta: TiaraWacana,

27 Dony, Matinya Metafiska Barat, (Jakarta: Komunitas Bambu, Gramedia, 2001), h.99

${ }^{28}$ Loren Bagus Metafisika, (Jakarta: Gramedia, 1991), h.5

${ }^{29}$ Muhammad Sulthon, 2003, Op cite, h.35

30 Joko Siswanto, Metafisika sistematik, (Yogyakarta: Taman Pustaka Kristen, 2004), h. 12

${ }^{31}$ Louis Katsoff, 1996, Op cite, h.76

32 Abdul Kadir Besar, 1995, Op cite, h.77 
berpengaruh terhadap realitas falsafah hidup dari sebelum kepercayaan kuno.

Keberadaan Sunan Kalijaga dalam kehidupan pada massa itu menyatu terhadap pola hidup bermasyarakat sebagai totalitas alam kehidupan karena sebagai Wali Asli Indonesia. Sunan Kalijaga bertugas untuk memberikan kebaikan, kemuliaan, kemanfaatan terhadap ingkungannya. Bahkan hinggga cara berpakaianpun ia tidak memakai jubah sebagai identitas kebesaran para wali, akan tetapi hanya menggunakan pakaian adat Jawa agar mereka tidak merasa asing dan lebih cepat menerima keadaannya. ${ }^{33}$ Fenomena tersebut bahwa sunan Kalijogo dapat menyelami budaya Jawa sebagai sebagai tradisi yang tidak dapat ditinggalkan begitu saja dalam kehidupan sehari-hari ditengah masyarakat .34 Adapun berbagai realitas ontologi yang digunakan oleh Sunan Kalijaga dalam esensi berdakwah.

\section{Hikmah bijaksana}

\section{a) Realitas Kesenian}

Kesenian rakyat yang dimanfaatkan untuk alat berdakwah ternyata membawa keberhasilan yang memuaskan, yaitu rakyat Jawa di saat itu hampir seluruhnya dapat menerima ajakan mengenai Islam. Karena dengan cara yang dipilihnya, pantaslah kalau orang membei gelar sebagai ahli budaya, dan memang banyak seni dari ciptaannya seperti:

1) Dalam seni pakaian beliau adalah orang pertama pencipta baju taqwa yangkemudian disempurnakan oleh Sultan Agung dengan destra nyamping dan dilengkapi dengan rangkaian keris. Sampai sekarang baju ini masih tetap digemari oleh masyarakat Jawa.

2) Mengenai seni suara juga tidak ketinggalan, beliau pencipta tembang Dandang gulo dan Dandang golo semarangan.

3) Kalau di zaman sebelum sunan Kalijogo, kebanyakan seni ukir hanya bermotifkan manusia dan binatang saja, akan tetapi setelah datangnya zaman para wali, terutama sunan Kalijogo yang menciptakan seni ukir bermotif dedaunan, bentuk gayor atau alat-alat tempat pengantungan gamelan dan bentuk

${ }_{33}$ Makhdlori Muhammad, Pertarungan Menuju Surga, Kala Ajaran Spiritual Di Tunggangi Ambisi, Kemelut Warisan Spiritual Syekh Siti Jenar VS Sunan Kalijogo, (Yogyakarta: Diva Press 2006), h. 63

34 Saymasuri Baidlowi, 1995, Op cite, h.96 
ornamen lainnya yang sampai sekarang mendapat tanggapan sebagai seni ukir nasional.

4) Sunan Kalijogo yang pertama kali mempunyai gagasan menciptakan bedug di masjid untuk memanggil orang shalat berjamaah. Mula-mula beliau memerintahkan seorang muridnya yang bernama Ki Pandan Arang (Sunan Bayat) untuk membuat bedug di masjid Semarang.

5) Grebeg maulud adalah prakarsa sunan Kalijogo, yaitu pada mulanya pengajian akbar yang di selenggarakan para wali di masjid Demak untuk memperingati Maulud nabi Muhammad Saw.

6) Suanan Kalijogo yang menciptakan Gong Sekaten artinya Gong Syahadataini yang maknanya dua kalimah syahadat. Gong sekaten tersebut mempunyai falsafat suara setiap alat gamelan yang menyatu diartikan: Disana.... disini... disitu mumpung masih ada waktu, yaitu mumpung masih diberi kesempatan hidup, berkumpulah dan cepat-cepat masuk agama Islam, kalau sudah mati biar tidak termasuk orang yang merugi.

7) Kalau sebelum sunan Kalijogo bentuk wayang adalah bergambar manusia. Oleh karena menggambarkan demikian memang haram hukumnya, maka sunan Kalijogo membuat kreasi baru. Bentuk wayang dirubah mirip karikatur, digambar dan diukir pada kulit binatang. Satu lukisan untuk satu wayang, sedangkan zaman sebelumnya satu lukisan untuk satu adegan. ${ }^{35}$

Di dalam kisah-kisah tentang Walisongo selalu disebutkan bahwa Sunan Kalijogo mempunyai peranan yang sangat besar dalam mengembangkan agama Islam di Indonesia, khususnya Jawa. ${ }^{36}$

\section{b) Realitas Idul Fitri}

Kegiatan tradisi lain yang mencerminkan keislaman adalah hari Raya Lebaran ('Idul Fitri). Orang Islam Jawa tradisional ini tidak mengenal Sholat 'Idul Fitri. Sebelum Lebaran diawali dengan kegiatan nyadran, yaitu ziarah kubur dan membersihkan makam nenek moyayangnya sebelum memasuk bulan Romadhon. Awal Romadhon ditandai dengan selamatan dan mengirim makanan kepada orang tua.

35 Ibid, h.97

${ }^{36}$ Hasanu Simon, Op, cite, h. 314 
Malam-malam kenduri tersebut berturut-turut disebut dalam bahasa Jawa malem selikur, malem telu, malem sela wee, malem pitu, dan malem songo. Kenduri pada hari-hari tertentu itu dimaksudkan untuk mengingatkan umat Islam akan datangnya lailatul qodar, namun sayangnya tidak diikuti dengan penjelasan tentang hakekat dan maksudnya. Jadi masyarakat hanya mengikuti upacara-upacara tersebut secara tradisi, dan anehnya hal itu dapat berlangsung selama 5 abad tanpa perubahan berarti dan tidak membawa pengaruh sama sekali terhadap perkembangan Islam secara kualitatif. ${ }^{37}$

\section{c) Realitas Bismillah}

Tradisi lain yang nampaknya juga basil kerja Sunan Kalijogo untuk mewarnai budaya masyarakat Jawa dengan nilai Islam adalah, setiap orang yang akan bekerja hams mengucapkan bismillah. Akan tetapi kata bismilah yang sebenarnya tidak sulit itu oleh Lidah Jawa kebanyakan diucapkan dengan semeilah. Bahkan cilakanya, kalau orang Islam ketika menghadapi musibah besar maupun kecil dianjurkan mengucapkan laa ilaha ilLallah, yang artinya tidak ada ilah selain Allah, yang terucap hanya Alah laaaa . ilah, yang artinya justru tidak ada ilah. Demikian pula waktu senja (magrib) juga dilarang keluar rumah karena waktu itu adalah candhik oloo. Kalau larangan mi dilanggar, orang dapat menjadi mangsa Bethoro Koloo, tidak dijelaskan pesan aslinya untuk tidak meninggalkan sholat magrib. 38 Perpindahan agama bagi orang Jawa justru terjadi setelah pendidikan model barat tersebar luas dan diikuti oleh seluruh masyarakat, khususnya melalui sekolahsekolah Kristen. ${ }^{39}$ Kokohnya budaya dan adat-istiadat orang Jawa yang berakar kepada nilai-nilai Islam secara ontologis.

\section{d) Realitas Alat kemakmuran}

Fundamental keberhasilan Sunan Kalijogo dalam membangun tradisi Jawa yang sudah sejak lama beliau selami dengan hikmah kebjaksanaan yang Islami adalah kepiawaiannya dalam membuat semacam filosofi yang memanfaatkan alat-alat pertanian yang digunakan masyarakat. Luku dan pacul adalah alat kemakrnuran bagi masyarakat petani. Oleh Sunan Kalijogo, bajak

\footnotetext{
37 Ibid, 315

38 Ibid, h.316

${ }^{39}$ Ibid, h.317
} 
(luku) yang tersusun atas tujuh bagian itu dianggap mengandung filosofi yang dalam yang sampai pada masa kini masih yaitu. ${ }^{40}$

1) Pegangan, artinya orang yang ingin mencapai cita-cita harus mempunyai pegangan, bekal yang cukup. Bagi orang Islam, pegangan hidup tidak lain adalah al-Qur'an dan Hadits.

2) Pancadan, mancad artinya bertindak. Kalau seseorang telah mempunyai pegangan dan bekal yang diperlukan, maka hendaknya segera bertindak, mengamalkan atau mengerjakannya, jangan ditunda-tunda lagi.

3) Tan ding, artinya membanding-bandingkan. Setelah bertindak, maka fikiran perlu membanding-bandingkan serta meneliti dengan alternatif atau kemungkinan yang lain dan kemudian dipilih mana yang dianggap lebih baik.

4) Singkal, diartikan metu saka ingakal. Setelah memikir-mikir, membandmg-bandingkan dan meneliti apa yang telah dikerjakan, maka akal akan menentukan siasat terbaik untuk dapat berhasil.

5) Kejen, artinya kesawijen, yaitu kesatuan atau pemusatan. Karena telah menemukan akal atau siasat, maka semua tenaga dan fikiran perlu disatukan.

6) Olang-aling, artinya sesuatu yang menutupi. Setelah tenaga dan fikiran berhasil disatukan maka cita-cita yang diinginkan sudah nampak terbayang di depan mata, tidak ada yang menutupi lagi.

7) Racuk, singkatan ngarah ingpucuk, yaitu menghendaki yang paling atas atau yang paling tinggi. Dengan petunjuk seperti di atas,betapapun tingginya cita-cita maka akhirnya akan dapat tercapai. ${ }^{41}$

Tentang filsafat pacul, setelah selesai membajak maka masih ada sisa-sisa tanah di sudut sawah yang belum terbajak. Peralatan pacul terdiri atas tiga bagian, yaitu:

a. Pacul-nya sendiri, yang merupakan singkatan dan ngipa take kang muncul, artinya dalam mengejar cita-cita tentu timbul godaan yang harus disingkirkan.

b. Bawak, singkatan obahing awak, menggerakkan badan. Semua godaan yang ada harus dihadapi dengan kerja keras.

40 Widji Saksono, Mengislamkan Tanah Jawa: Telaah Atas Metode Dakwah, (Jakarta: Rajawali Press, 1995), h.114

${ }^{41}$ Hasanu, Simon, Op cite, h.318 
c. Doran, singkatan ndedonga ing Pan geran, berdo'a kepada Tuhan.Upaya untuk mengejar cita-cita seringkali tidak cukup dengan mengandalkan kerja fisik saja, melainkan perlu disertai dengan do'a kepada Allah SWT.

\section{E. RELEVANSINYA BAGI PERKEMBANGAN MASYARAKAT PADA MASA KINI}

Dalam hubungannya dengan ontologi dakwah sunan Kalijogo relevansinya masyarakat secara filosofis, menurut Bustanudin Agus Ontologi Dakwah berkaitan dengan pandangan tentang hakikat di sekitar persoalan dakwah dengan demikian secara ontologi yakni keberadaan eksistensi dakwah apa yang nyata secara fundamental dalam dakwah. 42

Peran yang ada dakwah wali songo sangat relevan untuk menghadapi ragam permasalahan masyarakat masa kini dan mendatang yang berada dalam kancah kemajuan yang berkembang pesat, serta dipengaruhi oleh semakin maraknya sikap dan gaya hidup global. Dan pendalaman, yang akan memicu, mendorong serta membuahkan kreasi dan inovasi dalam kehidupan umat manusia. Martabat manusia dapat diwujudkan selama jiwanya dipenuhi dengan gairah yang tak kunjung padam untuk mengisi hidupnya dengan nilai-nilai yang bersifat kebaikan. Untuk itu semangat dakwah sebagai bentuk kesungguhan merupakan bagian visi pribadi siapapun dimanapun mereka berada, seluruh kehidupan untuk mencari dan mendapatkan ridha dari Allah Swt.

Sehingga tujuan hidupnya jelas, ibadahnya, kerja kerasnya, hidup dan matinya hanyalah untuk Allah semata. Ia tidak pernah terjerat kedalam nilai-nilai palsu atau hal-hal yang tanpa nilai (disvalues) sehinga tidak mengejar kesenangan hidup sebagai tujuan. ${ }^{43}$ Sehinga konteks dakwah jika dikaitan dengan kehidupan manusia akan menyangkut nilai dengan bidang yang sangat luas. Jelasnya dalam arti kegunaan, maka berkait dengaan nilai pragmatis dan utility, juga nilai dalam arti baik dan benar kerjakan yang baik dan hindari yang jahat. ${ }^{44}$

42 Muhammad Sulthon, Op cite, h.54

43 Amien Rais, Cakrawala Islam Antara Cita dan Fakta, (Bandung: Mizan), 1987), h.20

44 Soejadi, Pancasila Sumber Tertib Hukum Indonesia, (Yogyakarta: Lukman Ofset 1999), h. 21 


\section{E. KESIMPULAN}

1. Konsep ontologi berangkat dari sebuah pembahasan fenomena yang berarti sifat mendasar dari sebuah kenyataan yang terdalam. Reaksi saling tergantung dan saling memberi terdapat dalam totalitas, maknanya secara melekat pada diri manusia terbawa oleh keberadaan manusia, dalam kehidupan secara totalitas.

2. Ontologi dakwah Sunan Kalijogo menjadikan khazanah sebagai sarana untuk menetralisir anggapan masyarakat zaman dahulu yang masih mengarah pada kemusyrikan secara sedikit demi sedikit menuju pada ketauhidan.

3. Peran yang ada dakwah wali songgo masih relevan untuk menghadapi ragam permasalahan masyarakat masa kini dan mendatang yang berada dalam kancah kemajuan yang berkembang pesat, serta dipengaruhi oleh semakin maraknya sikap dan gaya hidup global.

\section{Daftar Pustaka}

Aqih, Suminto, Dakwah dan Perubahan Sosial, Jakarta: Bulan Bintang, 1990

Bustanuddin, Agus Pengembangan Ilmu-Ilmu Sosial, Studi Banding Antara Pandangan Ilmiah dan Ajaran Islam, Jakarta: Gema Insani Press, 1999

Edi, Amin, Islam Politik dan Demokrasi Beragama, Jakarta: Pelita, 1997

Fuad,Amysari Islam Kaffah, Tantangan Sosial, Teologi, Filsafat dan Aplikasinya di Indonesia, Jakarta: Gema Insani Press,1995

Isa, Anshari, Mujahid Dakwah, Bandung: Diponegoro, 1984

Baidlowi, Saymasuri, Kisah Wali songo, Surabaya: Apollo, 1995

Besar, Abdul Kadir, Cita negara Persatuan, Jakarta : BP-7 Pusat, 1995

Dony, Matinya MetafiskaBarat, Jakarta: Komunitas Bambu, Gramedia, 2001

Dzikron, Abdullah, Filsafat Dakwah, Semarang: Diktat Fakultas Dakwah IAIN Walisonggo Semarang, 1993

Encon Darsono, Wikatna, Agama dan Kerukunan Penganutnya, Bandung: Al Ma'arif, 1980

Effendi, Zarkasi, Metode Dakwah Kepada Suku Terasing, Jakarta: Departemen Agama-RI, 1978 